\title{
Dental Fluorosis Status in School Children of Jaipur (Raj) India
}

\author{
Gupta Rashmi ${ }^{1}$, Sharma Akhil ${ }^{2}$ Gaur Kusum ${ }^{3}$, Zafer Afifa ${ }^{4}$ Manohar Rk ${ }^{5}$ \\ 1,3,4,5 (PSM Department, SMS Medical College, Jaipur (Raj) / RUHS University, Jaipur, India \\ ${ }^{2}$ (Dentistry Department, Balagi Clinic Jaipur (Raj) / RUHS University, Jaipur, India
}

\begin{abstract}
:
Research Question: Dental Fluorosis Status in School Children of Jaipur (Raj) India Objectives: To find out the Dental Fluorosis and its associating factors among students. Methodology: A cross-sectional observational study was carried out on 3200 children of 5-16 years of age of 20 elementary schools of urban and rural area of Jaipur in year 2011. Socio-demographic data were collected from parents of children and thorough dental check-up was arranged by a dentist for these children. Children with fluorosis were identified. Data in details were collected as per pre-designed proforma. Data collected were analysed and inferred with chi-square test. Result: $34.5 \%$ of children were diagnosed as having dental fluorosis. Dental fluorosis was significantly $(P<0.05)$ more in rural areas $(43.94 \%)$ than in the urban areas $(25.06 \%)$. Variation in proportion of cases as per the age was also found to be highly significant $(P<0.001)$ with M:F ratio 1.18(P>0.05).Conclusion: More than one third students were having dental fluorosis. It was found associated with rural areas and age but sex was not associated
\end{abstract}

Keywords - Dental fluorosis, Socio-demographic factors, chi-square Test

\section{INTRODUCTION}

Upto a certain extent fluoride ingestion is useful for bone and teeth development, but excessive ingestion causes a disease known as Fluorosis. While the WHO standards permit only $1.5 \mathrm{mg} / \mathrm{l}$ as a safe limit of fluoride in drinking water for human consumption, people in several districts in Rajasthan are consuming water with fluoride concentrations of up to $24 \mathrm{mg} / \mathrm{l}$. It continues to be an endemic problem. More and more fluoride endemic areas are being discovered regularly.

Endemic fluorosis is widely prevalent in China, India, Middle East, North Africa, Ethiopian rift valley and other parts of Africa. High incidence of endemic fluorosis in India is due to the fact that large areas of the country contain water supplies having high levels of fluoride Children in the age group of 0 to 12 years are the most prone to fluorosis as their body tissues are in formative / growth stage during this period.[1]

In India, Flurosis problem has reached alarming proportions affecting at least 17 states (Andhra Pradesh, Tamil Nadu, Uttar Pradesh, Gujarat, Rajasthan where 50 to 100 percent districts were affected).

In Rajasthan, all the 33 districts have been declared as fluorosis prone areas and Jaipur District is one of the worst affected with Chaksu, Dudu, Phagi, and Sanganer being the worst affected areas [2]. In Rajasthan, Fluorides in drinking water comes from indigenous rocks and ground water around the mica mines as Rajasthan has rich sources of mica.

So the present study is designed to find out the associating factors of dental fluorosis in Jaipur district.

\section{Materials And Methods}

The present Cross Sectional Observational study was carried out in year 2010 on 3200 School going children aged 5-16 years. As per Department of Education, Jaipur District has four urban blocks; namely Jaipur East, Jaipur West, Jhotwara and Sanganer. Out of these Jaipur west and Jhotwara were selected randomly for the study. Likewise the rural area of Jaipur District is constituted by 13 Panchayat Samities, out of that two Amber and Jamwaramgarh were selected randomly for the study.

Sample size: Sample size was calculated 1600 subjects at $95 \%$ confidence limit with $10 \%$ allowable error assuming $20 \%$ prevalence of dental fluorosis. So for the study purpose 1600 children from schools of rural areas and 1600 children from schools of urban areas was included in study.

List of rural and urban schools in the selected area was procured from the office of Deputy Director of Education Department, Jaipur District. Schools were also selected randomly using the simple random technique from the procured list to achieve the desired sample size i.e. 1600 from rural and 1600from urban areas.

Every Institutional Head of identified school was informed about the purpose and methodology of the study and those who had given consent were given the consent form and proforma for parents. $\mathbf{1}^{\text {st }}$ part of the designed proforma consisting general information about the child and his family was given to parents of the child through the respective class teachers. After the forms were duly filled up by the parents of the study subjects, it was subsequently collected from the class teachers. Identified Schools were visited on the mutually pre-decided date and time so as to examine the maximum number of study subjects by a dentist. Children were 
examined in the school premises at a suitable place in presence of respective class teachers with the subjects seated in ordinary chairs in natural day light for illumination, avoiding direct sunlight.

Finally the screened students were examined thoroughly for dental and periodontal diseases, after reassuring them and making them comfortable and taking all necessary aseptic precautions. Part second of the predesigned proforma was filled after examining each child. The same procedure was in identified schools till the sample size of 1600 students of rural and 1600 students of urban area were achieved.

Dentition status and treatment need was assessed using Oral Health Assessment Form 2004 [3] by a dentist. Only relevant information related with periodontal diseases along with general information was collected on predesigned proforma.

Data thus collected were compiled, analyzed with Microsoft excel 2007.

\section{Results}

The present study has been designed to find out associating factors of dental fluorosis amongst students in 5-16 years of age group studying in elementary schools of Jaipur district.

Of the total 3200 students (1600 rural and 1600 urban) found in 20 identified schools in the study, dental fluorosis was found in 1088 (34\%) surveyed students.

Present study revealed that rural children had significantly more $(\mathrm{p}<0.001)$ dental fluorosis than the urban children i.e. $43.94 \% \mathrm{v} / \mathrm{s} 25.06 \%$.

Further it is revealed that difference in distribution of dental fluorosis cases proportion according to age was also having highly significant variation $(\mathrm{p}<0.001)$ falling maximum proportion in the age groups of $11-13$, followed by $8-18$ years, 5-8 years and 14-16 years of age groups.

Present study also found that males significantly predominated $(\mathrm{p}=0.02)$ in having dental fluorosis than female children i.e. $\mathrm{M}: \mathrm{F}=1.17: 1$

Further it was found in this study that difference in distribution of dental fluorosis cases proportion according to father's education and mother's education was also having significant variation $(p=0.005$ and $\mathrm{p}<0.001$ respectively). It was observed that as education increases proportion of dental fluorosis cases decreases. It was also revealed that mother's education had more role in comparison to father's education.

When water source for drinking was asked, it was also found to associated with type of water source i.e. children consumed tape water supply and well water supply were having significantly $(p<0.001)$ less dental fluorosis in comparison to children consumed handpump water supply and tube-well water supply.

In the present study mouth rinsing and frequency of teeth cleaning was not associated with dental fluorosis ( $\mathrm{p}=0.361$ and $\mathrm{p}=0.605$ respectivly. And surprisingly dental fluorosis was observed significantly $(\mathrm{p}<0.001)$ less in children who either did not clean their teeth even once of clean their teeth with their finger rather than who clean their teeth with tooth paste or tooth powder.

\section{Discussion}

In the present study, 34.5 percent of children were diagnosed as having dental fluorosis. This is similar to the findings in rural areas of Udaipur i.e 36.36 percent and at Kerala (35.36 percent). On the other hand, a lower prevalence (12.52 percent) was recorded by Jain (1979) [4] at Naila and S Saravanan (2008) [5] at Tamil Nadu recorded 31.4 percent. This difference in the proportion may be due to the more use of toothpaste and tooth powder nowadays which may contaion fluorides to make foams. This fact was further proved in the present study that dental fluorosis was observed significantly less $(\mathrm{p}<0.001)$ in children who either did not clean their teeth even once of clean their teeth with their finger rather than who clean their teeth with tooth paste or tooth powder.

Maximum (43.94\%) in the present study were observed in the rural areas than in the urban areas $(25.06 \%)$ and this difference was significant $(\mathrm{P}<0.001)$. This study was well supported by National Oral Health Survey \& Fluoride Mapping 2004, India [6] and Baskaradoss, JK(2008) [7] This may be because of the fact in the rural belt that most of the students use ground water in comparison to urban areas. This ground water is untreated water. This fact is further supported with the observation that consumers of water from handpumps and tube wells had significantly $(\mathrm{P}<0.001)$ more dental fluorosis than consumers of tap water and well water.

In case of fluorosis, variation in proportion of cases as per the age was also found to be highly significant $(\mathrm{P}<$ 0.001). Similar finding were of Jain (1979) [4] Dhar et al (2007) [8], S Saravanan (2008) [5] Poornima Tiwari et al(2010) [9], Rajesh Kr. Yadav et al (2012) [10]. This may attributed to the fact that most of the teeth in the 5 to 6 years of age group are deciduous (primary teeth), and much of the mineralization process occurs in the intra-uterine phase, where the placenta serves as a partial barrier to the transfer of fluoride to the developing primary teeth.

In the present study male preponderance was observed with $\mathrm{M}: \mathrm{F}$ ratio 1.17:1 ( $\mathrm{P}=0.02)$. In National Oral Health Survey and Fluoride Mapping 2004, India [6], S Saravanan (2008) [5], Poornima Tiwari et al (2010) [9], no significant difference was observed. This may be attributed to excessive physical activity by males, thus resulting in more consumption of water and in turn more intake of fluorides. 
Significant variation was observed in the present study as per the father's education and mother's education. Mother's education was observed to be more associateted than father's education $(\mathrm{P}<0.001$ and $\mathrm{P}=0.005$ respectively). This may be because of the fact that mother are in more contact with children than fathers.

Significant $(\mathrm{P}<0.001)$ difference was found in the distribution of the disease according to source of drinking water with more drinking water in ground water consumers. Whereas Baskaradoss, JK (2008) [7] in his study at Tamilnadu found that the prevalence of dental fluorosis was higher in children who consumed pipe water as compared to children who consumed ground water and this difference may be that attributed to the fact the study area had no authorized water supply. The private supplied supply water from tube wells only, even in condition of availability of tap water [11].

No association was observed between dental fluorosis with mouth rinsing and frequency of teeth cleaning $(\mathrm{P}=0.361$ and $\mathrm{P}=0.605$ respectively). Baskaradoss, $\mathrm{JK}(2008)$ also did not observe any association between dental fluorosis and oral hygiene habits [7].

Highly significant $(\mathrm{P}<0.001)$ difference was found in proportion of cases as per type of material used for cleaning teeth with maximum cases in those who used either tooth paste or tooth powder. These findings may be because of the tooth paste and tooth powder available in the market are fluroidated, therefore their dental use in younger children increase the chance of having dental fluorosis [12].

\section{Conclusion}

Dental fluorosis was found to be associated with rural areas, age, sex, education of father and education of mother. Mother's education is more associated with dental fluorosis than father's education.

Dental fluorosis was also found to be associated with source of drinking water supply and type of material used for teeth cleaning. Children using ground water without treatment were having more chances of dental fluorosis. Likewise children using tooth paste or tooth powder were having more chances of having fluorosis. children.

Frequency of teeth cleaning and mouth rinsing was not found to be associated with dental fluorosis in

\section{References}

[1]. Fluoride and Fluorosis A review report on Fluorosis http://www. krassindia.org/downloads/ebook1.pdf.

[2]. Indo-Asian News Service. Fluorosis on the rise in Rajasthan Jaipur. January 31, 2004.

[3]. World Health Organization. Oral Health Surveys - Basic Methods; WHO 2004.

[4]. Singhal J.P. An Epidemiological Study of Dental and Periodontal diseases among school children in Ajmer City. Thesis submitted for the degree of MD. (P.S.M.), University of Rajasthan 1981.

[5]. S Saravanan. Prevalence of Dental Flurosis Among Primary School Children in Rural Areas of Chidambaram Taluk, Cuddalore District, Tamil Nadu, India Indian Journal of Community Medicine, Vol. 33, Issue 3, July 2008.

[6]. National Oral Health Survey and Fluoride Mapping. An Epidemiological Study of Oral Health Problems and Estimation of Fluoride Levels in Drinking Water. Dental Council of India, New Delhi, 2004; 32 : 67-78

[7]. Baskaradoss, JK. Prevalence of dental fluorosis and associated risk factors in 11-15 year old school children of Kanyakumari District, Tamilnadu, India : A cross sectional survey. Indian J Dent Res. 2008 Oct-Dec; 19 (4) : 297-303.

[8]. Dhar V et al. Prevalence of gingival diseases, malocclusion and fl uorosis in school-going children of rural areas in Udaipur district. J Indian Soc Pedod Prev Dent - June 2007.

[9]. Poornima Tiwari et al. Dental fluorosis and its association with the use of fluoridated toothpaste among middle school studen ts of Delhi, 2010; Volume: 64, Issue: 1 : 1-6.

[10]. Rajesh Kr. Yadav et al. Endemic Dental Fluorosis and Associated Risk Factors in Dausa District, Rajasthan, World Applied Sciences Journal, 2012; 16 (1) : 30-33, IDOSI Publications.

[11]. Suma G, Crowding, Spacing And Closed Dentition And Its Relationship With Malocclusion In Primary Dentition. International Journal of Clinical Dental Science 2010; 1 (1)

[12]. Ana Karina Mascarenhas. Risk factors for dental fluorosis : A review of the recent literature. American Academy of Pediatric Dentistry (Pediatr Dent, 2000; $22: 269-277$.

\section{Journal Papers:}

[1] M Ozaki, Y. Adachi, Y. Iwahori, and N. Ishii, Application of fuzzy theory to writer recognition of Chinese characters, International Journal of Modelling and Simulation, 18(2), 1998, 112-116. (8) Note that the journal title, volume number and issue number are set in italics.

Books:

[2] R.E. Moore, Interval analysis (Englewood Cliffs, NJ: Prentice-Hall, 1966)

Chapters in Books:

[3] P.O. Bishop, Neurophysiology of binocular vision, in J.Houseman (Ed.), Handbook of physiology, 4 (New York: Springer-Verlag, 1970) $342-366$.

Theses:

[4] D.S. Chan, Theory and implementation of multidimensional discrete systems for signal processing, doctoral diss., Massachusetts Institute of Technology, Cambridge, MA, 1978.

Proceedings Papers:

[5] W.J. Book, Modelling design and control of flexible manipulator arms: A tutorial review, Proc. 29th IEEE Conf. on Decision and Control, San Francisco, CA, 1990, 500-506 
Table no. I

\begin{tabular}{|c|c|c|c|c|}
\hline S. No. & Area & $\begin{array}{l}\text { Total } \\
(\mathrm{N}=3200)\end{array}$ & Flurosis & $\begin{array}{c}\text { Chi-Square Test } \\
\text { P Value LS }\end{array}$ \\
\hline 1 & Rural & 1600 & 703 & 125.29 at $1 \mathrm{DF}$ \\
\hline 2 & Urban & 1600 & 401 & $\mathrm{P}<.001 \mathrm{HS}$ \\
\hline S. No. & \multicolumn{4}{|l|}{ Age group (in years) } \\
\hline 1 & 5 to 7 & 536 & 131 & \multirow{4}{*}{$\begin{array}{c}35.309 \text { at } 3 \mathrm{DF} \\
\mathrm{P}<.001 \mathrm{HS}\end{array}$} \\
\hline 2 & 8 to 10 & 1098 & 371 & \\
\hline 3 & 11 to 13 & 1362 & 527 & \\
\hline 4 & 14 to 16 & 204 & 75 & \\
\hline S. No. & \multicolumn{4}{|l|}{ Sex Wise } \\
\hline 1 & Male & 1632 & 596 & \multirow{2}{*}{$\begin{array}{c}5.407 \text { at } 1 \mathrm{DF} \\
\mathrm{P}=0.02 \mathrm{~S}\end{array}$} \\
\hline 2 & Female & 1570 & 511 & \\
\hline S. No. & \multicolumn{4}{|l|}{ Father's Education } \\
\hline 1 & Illiterate & 678 & 259 & \multirow{7}{*}{$\begin{array}{c}18.797 \text { at } 6 \mathrm{DF} \\
\mathrm{P}=0.005 \mathrm{~S}\end{array}$} \\
\hline 2 & Primary & 551 & 199 & \\
\hline 3 & Middle & 652 & 237 & \\
\hline 4 & Secondary & 739 & 245 & \\
\hline 5 & Higher secondary & 366 & 95 & \\
\hline 6 & Graduation & 171 & 54 & \\
\hline 7 & Post graduation & 43 & 15 & \\
\hline & \multicolumn{4}{|l|}{ Mother's Education } \\
\hline 1 & Illiterate & 1954 & 732 & \multirow{7}{*}{$\begin{array}{c}35.995 \text { at } 6 \mathrm{DF} \\
\mathrm{P}<.001 \mathrm{HS}\end{array}$} \\
\hline 2 & Primary & 498 & 172 & \\
\hline 3 & Middle & 376 & 95 & \\
\hline 4 & Secondary & 265 & 69 & \\
\hline 5 & Higher secondary & 81 & 25 & \\
\hline 6 & Graduation & 36 & 9 & \\
\hline 7 & Post graduation & 17 & 2 & \\
\hline
\end{tabular}

Table no. II

\begin{tabular}{|c|c|c|c|c|}
\hline S.NO. & Water Source & $\begin{array}{l}\text { Total } \\
(3200)\end{array}$ & Fluorosis & $\begin{array}{c}\text { Chi-Square Test } \\
\text { P Value LS }\end{array}$ \\
\hline 1 & Tap & 2325 & 749 & \multirow{4}{*}{$\begin{array}{l}22.777 \text { at } 3 \mathrm{DF} \\
\mathrm{P}<.001 \mathrm{HS}\end{array}$} \\
\hline 2 & Handpump & 347 & 140 & \\
\hline 3 & Tubewell & 480 & 201 & \\
\hline 4 & Well & 48 & 14 & \\
\hline S.No. & \multicolumn{4}{|l|}{ Mouth Rinsing per Day } \\
\hline 1 & Never & 943 & 340 & \multirow{3}{*}{$\begin{array}{c}2.039 \text { at } 2 \mathrm{DF} \\
\mathrm{P}=0.361 \mathrm{NS}\end{array}$} \\
\hline 2 & Sometime & 1947 & 653 & \\
\hline 3 & Always after meals & 310 & 111 & \\
\hline S.No. & \multicolumn{4}{|l|}{ Teeth Cleaning Material } \\
\hline 1 & Fingers & 248 & 88 & \multirow{6}{*}{$\begin{array}{r}22.086 \text { at } 5 \mathrm{DF} \\
\mathrm{P}<.001 \mathrm{HS}\end{array}$} \\
\hline 2 & $\begin{array}{l}\text { Tooth brush and Tooth } \\
\text { Paste }\end{array}$ & 2113 & 701 & \\
\hline 3 & $\begin{array}{l}\text { Tooth brush and Tooth } \\
\text { powder }\end{array}$ & 316 & 130 & \\
\hline 4 & Datun & 240 & 101 & \\
\hline 5 & Charcoal with finger & 45 & 20 & \\
\hline 6 & Don't Clean & 238 & 64 & \\
\hline S.No & \multicolumn{4}{|c|}{ Frequency of teeth cleaning } \\
\hline 1 & Zero & 238 & 75 & \multirow{5}{*}{$\begin{array}{l}2.723 \text { at } 4 \mathrm{DF} \\
\mathrm{P}=0.605 \mathrm{NS}\end{array}$} \\
\hline 2 & $<1$ & 138 & 43 & \\
\hline 3 & Once & 1884 & 661 & \\
\hline 4 & Twice & 828 & 292 & \\
\hline 5 & $>$ Twice & 112 & 43 & \\
\hline
\end{tabular}

Figure 1

Florosis in School Children

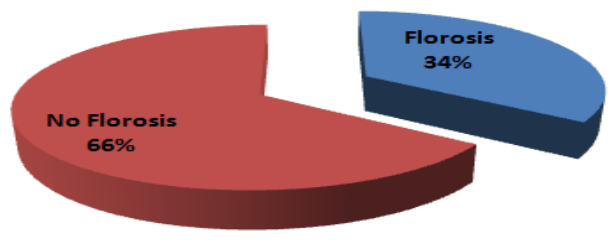

